\title{
Macrofungi in Some Forests of Telangana State, India
}

\author{
Gudikandula Krishna, Burra Samatha, S. V. S. S. S. L. Hima Bindu Nidadavolu, \\ Metuku Ram Prasad, Byram Rajitha, and Maringanti Alha Singara Charaya
}

Department of Microbiology, Kakatiya University, Warangal 506009, India

Correspondence should be addressed to Gudikandula Krishna; krishnagudikandula@gmail.com

Received 25 September 2014; Revised 27 December 2014; Accepted 27 December 2014

Academic Editor: Ángel Domínguez

Copyright ( 2015 Gudikandula Krishna et al. This is an open access article distributed under the Creative Commons Attribution License, which permits unrestricted use, distribution, and reproduction in any medium, provided the original work is properly cited.

\begin{abstract}
The fruiting bodies of macrofungi were collected from some forests, fences, waste fields, timber depots of Telangana state during rainy season. This is an attempt to give a broad picture of diversity of macrofungi belonging to the class Basidiomycetes in some forest areas of Telangana region. A total number of 50 fruiting bodies were collected and cultured and among them only ten were identified based on their macroscopic features and molecular identification since they showed good lignolytic activity.
\end{abstract}

\section{Introduction}

The total forest cover in India according to the latest Forest Report 2013 is 69.8 million hectares and this constitutes $20.64 \%$ of the geographic area. The state of Telangana is one of the progressive states in the southern part of India with an area of 114,840 sq.km, while the recorded forest area is $29242.08 \mathrm{sq.km}$. The annual rainfall is between 900 to $1500 \mathrm{~mm}$ in northern Telangana and 700 to $900 \mathrm{~mm}$ in southern Telangana, from the southwest monsoons and it is a semiarid area and has a predominantly hot and dry climate. The Basidiomycota is the second largest phylum of kingdom Fungi, with approximately 23,000 species [1] including many of the common macroscopic forest fungi (e.g., mushrooms, shelf fungi). Mushroom is a general term utilised mostly for the fruiting body of the macrofungi, belongs to Ascomycota and Basidiomycota, and represents only a short reproductive stage in their life cycle. Investigations on the taxonomy and diversity of macrofungi are gaining importance, as many macrofungi are facing a threat of extinction due to environment destruction. Wild mushrooms have deep biological and economical impact. Information on mushroom diversity is important because of its major functions in natural and organised eco-schemes as ectomycorrhizal fungi. The fungal group becomes a significant component for reforestation programs. Furthermore, they are significant as nourishment source for human beings and animals [2]. The macrofungi were also used as a bioindicator of environmental quality [3]. Most of the fleshy and gilled macrofungi were prevalent in the rainy times of the year as this time is favourable for their output, since there is ample moisture, favourable warmth, relative humidity, and sunshine, which furthermore aids the macrofungi in the decomposition of dead organic tissue. The early dry time of the year collection was predominated by the polypores since there is decline in rainfall and relative humidity, boost in warmth, and sunshine and most of the fleshy macrofungi will not withstand these conditions. During rainy season, there is abundant growth of several kinds of Basidiomycetes. Many fungal species groups do not produce visible fruit bodies or other species-specific characteristics, or these characteristics are extremely rare and cannot be detected in traditional surveys; hence these can be studied using molecular methods [4-6]. Further, Basidiomycetes are considered to be a very interesting group of fungi with their exceptional adjustment abilities and as natural lignocellulose degraders with different ecological groups such as white rot, brown rot, and leaf litter fungi [7]. Many kinds of macrofungi are not edible but possess variety of pharmaceutical and medicinal qualities. A fraction of complete fungal wealth has been subjected to scientific scrutiny and mycologists continue to unravel the unexplored and hidden wealth; one-third of fungal diversity of the globe exists in India and of this only $50 \%$ is characterized until now [8]. About 10,000 species within the overall fungal estimates of 1.5 million belong to 
this group. Mushrooms alone are represented by about 41,000 species, of which approximately 850 species are recorded from India [9]. Some of the wild edible mushrooms have been reported from South West India [10]. The first listed Indian Fungi was published [11] and that was revised by Vasudev [12] and extra additional lists appeared in between culminating with the fungi of India (Bilgrami et al. [13]).

The present communication is the collection, culture, identification, and preservation of the macrofungi in some forests of Telangana region. This study adds extra information to the present knowledge on the data of diversity of fungi in Telangana region and also to understand their bioprospects.

\section{Materials and Methods}

2.1. Study Area. The fruiting bodies of white rot fungi were collected in rainy season from the forest of Etunagaram, Bhadrachalam, Kothagudem, Narsampet, Ilandhu, Khammam, Bodhan, and Nirmal of Telangana region.

2.2. Culturing and Preservation. The collected fruit bodies were cultured for their mycelial growth as per the method suggested [14]. A small piece of fruiting body was dipped in $0.01 \%$ mercuric chloride to remove surface contamination and washed several times with distilled water to remove the traces of mercuric chloride and transferred aseptically on to $3 \%$ malt extract agar [15] slants and was incubated for 57 days. The mycelium collected from the growing edge of those slants was transferred on to new malt extract agar slants and incubated further 5-7 days to obtain pure culture. Pure cultures were subcultured on malt extract agar slants and plates every fortnight.

2.3. Characterization of Macrofungi. Based on macroscopic features, namely, size, shape, sporocarp nature, color, spore print, margin of pileus, characters of lamella, spacing of gills, characters of the stipe, and the presence or absence of veils on stipes, the fungi were identified, http://en.wikipedia.org/ wiki/Template:Mycomorphbox.

\subsection{Identification of Macrofungi}

2.4.1. Macroscopic Identification. Seven mycological characters useful in tentative identification of mushrooms are hymenium type, cap shape, gills, stipe character, color of the spore print, ecological type, and edibility.

2.4.2. Molecular Identification. Based on their lignolytic activity (data not shown here) ten species of wild macrofungi were selected for confirmation of their identities using molecular methods (see Figure 1). Collected fruiting bodies are initially cultured on malt agar (MEA), and the genomic DNA of the macrofungi was extracted using modified CTAB method [16]. The genomic DNA of the macrofungi was then subjected to PCR to amplify the ITS regions of the nuclear ribosomal DNA using two primers: ITS $1\left(5^{\prime}\right.$ TCCGTAGGTGAA CCTTGCGG3') and ITS 4
(5'TCCTCCGCTTATTGATATGC3') [17]. The PCR products were then purified using QIAGEN purification kit following the manufacturer's instructions and the purified PCR products were sent to SciGenom, Cochin, for outdoor DNA sequencing. Related gene sequences for each of the macrofungal specimens were obtained from NCBI GenBank and then automatically aligned using ClustalW program incorporated in BioEdit v. 7.1.9 [18]. Manual sequence alignments were then performed using Bioedit to allow maximum sequence similarity. Finally, phylogenetic tree was constructed based on maximum parsimony using PAUP v. 4.0 b10 [19].

\section{Results}

The fruiting bodies of white rot fungi were collected in rainy season from few forest areas of Telangana state (Table 1). The collected fruit bodies were cultured until the pure cultures were obtained. The lists of identified wild mushrooms were depicted in Tables 2 and 3. The fungi that belong to Polyporales are more in number than other orders. Schizophyllum radiatum belong to the order Agaricales. All the collected fungi were saprotrophic and were not edible. Based on seven mycological characters they were characterized. The climatic conditions in Telangana are congenial for prevalence of macrofungi and hence recorded maximum genera. During the systematic surveys at different forests of Telangana, total 50 mushroom samples were collected and these samples belong to different genera out of which only 10 mushroom samples were identified based on their lignolytic activity (data not shown here) and were identified basing on the molecular identification and macroscopic characters. All collected mushrooms have been deposited in the department herbarium with accession numbers. The ten identified mushrooms by molecular level are Trametes versicolor (GenBank Accession number HF953984), Pycnoporus cinnabarinus strain SYBC-L14, Daedaleopsis flavida strain 5A, Trametes elegans voucher, Trametes hirsuta, Fomitopsis feei (GenBank Accession number AY 515327.1), Trametes gibbosa (GenBank Accession number AY351924.1), Trametes elegans GenBank (Accession number AY351925.1), Ganoderma lucidum, and Schizophyllum radiatum (GenBank Accession number HE863742.1).

\section{Discussion}

In Basidiomycotina more than 2000 species of edible mushrooms are reported in the publications from different components of the world. People all over Asian countries in the twentieth century know that mushrooms are important biosource of novel secondary metabolites. In India, the alternative systems of medicine utilize the curative properties of mushrooms. Secondary metabolites of these mushrooms are chemically diverse and possess a broad spectrum of biological activities, which are explored in traditional medicines [20]. In India, several mushrooms have been reported as medicinal mushrooms which have antioxidant, antimicrobial, and anti-inflammatory activity with antitumor 


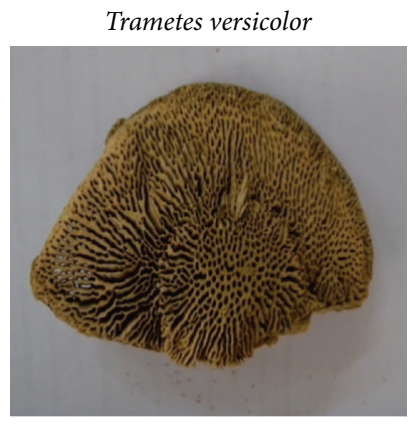

Daedaleopsis flavida strain $5 \mathrm{~A}$

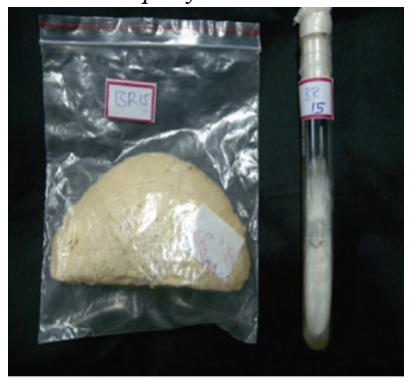

Trametes hirsuta

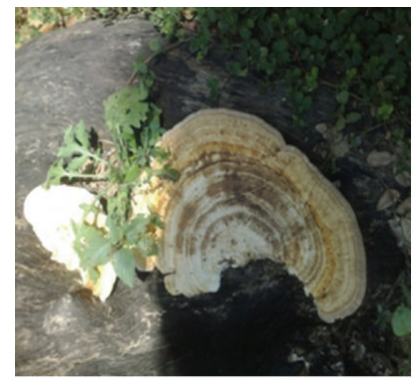

Trametes gibbosa

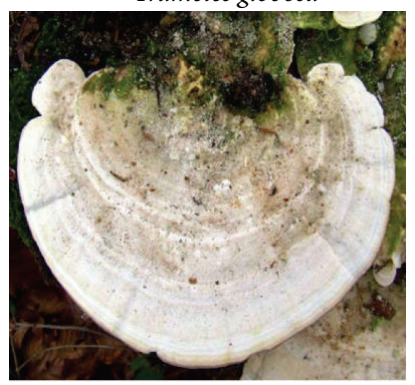

Schizophyllum radiatum

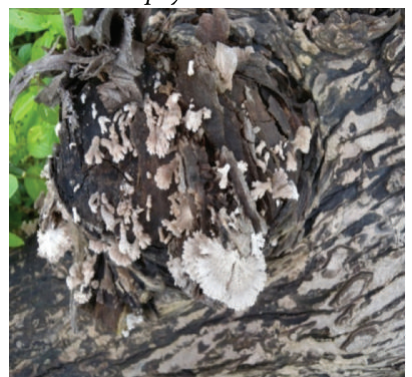

Pycnoporus cinnabarinus strain SYBC-L14

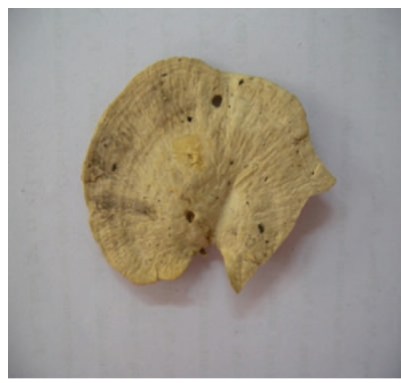

Trametes elegans voucher

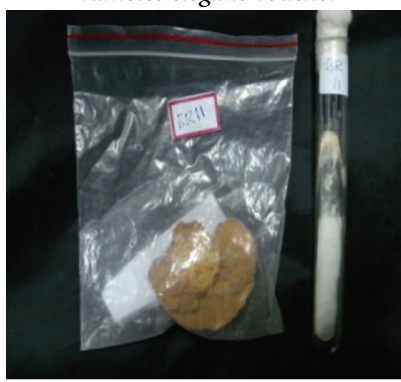

Fomitopsis feei

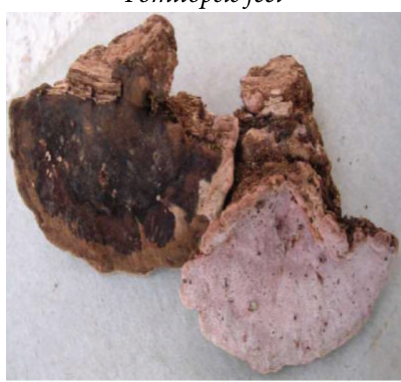

Trametes elegans

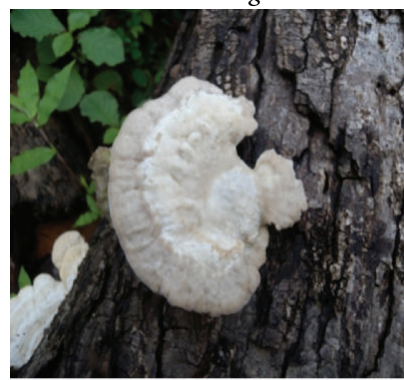

Ganoderma lucidum

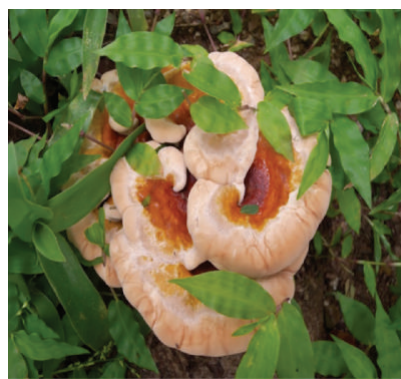

FIGURE 1: Photographs of identified macrofungi. 
TABLE 1: List of macrofungi collected in some forests of Telangana state.

\begin{tabular}{|c|c|c|c|c|}
\hline Site Number & Site name & Strain name & Source & Altitude \\
\hline \multirow{16}{*}{1} & \multirow{7}{*}{ Eturnagaram forest } & Abortiporus biennis & Ground-dwelling & \multirow{16}{*}{$\begin{array}{l}18^{\circ} 20^{\prime} 20^{\prime \prime} \mathrm{N}, \\
80^{\circ} 25^{\prime} 45^{\prime \prime} \mathrm{E}\end{array}$} \\
\hline & & Agaricus xanthodermus & Hardwood & \\
\hline & & Cantharellus subalbidus & Hardwood & \\
\hline & & Tyromyces sp. & Tree & \\
\hline & & Gleophyllum sp. & Tree & \\
\hline & & Gomophus sp. & Tree & \\
\hline & & Trametes pubescens & Dead wood & \\
\hline & \multirow{9}{*}{ Eturnagaram Timber Depot } & $\begin{array}{c}\text { Trametes elegans } \\
\text { voucher }\end{array}$ & Wood log & \\
\hline & & Pycnoporus cinnabarinus & Wood log & \\
\hline & & Trametes hirsuta & Wood log & \\
\hline & & Oligoporus sp. & Wood log & \\
\hline & & Schizophyllum radiatum & Wood log & \\
\hline & & Trichaptum & Wood log & \\
\hline & & Trametes versicolor & Wood log & \\
\hline & & Trametes gibbosa & Wood log & \\
\hline & & Fomitopsis feei & Tree & \\
\hline \multirow{10}{*}{2} & \multirow{10}{*}{ Bhadrachalam forest } & Auricularia auricula & Wood log & \multirow{10}{*}{$\begin{array}{l}17^{\circ} 40^{\prime} 12^{\prime \prime} \mathrm{N} \\
80^{\circ} 52^{\prime} 48^{\prime \prime} \mathrm{E}\end{array}$} \\
\hline & & Clitocybe philophylla & Tree & \\
\hline & & Tremella foliacea & Fallen branches & \\
\hline & & Trametes hirsuta & Dead wood & \\
\hline & & Daedaleopsis flavida & Fallen branches & \\
\hline & & Ganoderma lucidum & Wood log & \\
\hline & & Stereum hirsutum & Dead wood & \\
\hline & & Trametes betulina & Wood log & \\
\hline & & Ganoderma sp. & Wood log & \\
\hline & & Inonotus hispidus & Tree & \\
\hline \multirow{5}{*}{3} & \multirow{5}{*}{ Bodhan } & Phellinus igniarius & Tree & \multirow{5}{*}{$\begin{array}{r}18^{\circ} 40^{\prime} 12^{\prime \prime} \mathrm{N} \\
77^{\circ} 54^{\prime} 0^{\prime \prime} \mathrm{E}\end{array}$} \\
\hline & & Tremella aurantia & Wood log & \\
\hline & & Stereum ostrea & Tree barks & \\
\hline & & Dichomitus sp. & Wood log & \\
\hline & & Trametes sp. & Wood log & \\
\hline \multirow{5}{*}{4} & \multirow{5}{*}{ Nirmal } & Ganoderma applanatum & Tree & \multirow{5}{*}{$\begin{array}{l}19^{\circ} 6^{\prime} 0^{\prime \prime} \mathrm{N} \\
78^{\circ} 21^{\prime} 0^{\prime \prime} \mathrm{E}\end{array}$} \\
\hline & & Amauroderma & Wood log & \\
\hline & & Trametes ochracea & Wood log & \\
\hline & & Trametes elegans & Wood log & \\
\hline & & Pycnoporus coccineus & Wood log & \\
\hline \multirow{5}{*}{5} & & Pleurotus sp. & Wood log & \multirow{5}{*}{$\begin{array}{l}17^{\circ} 36^{\prime} 0^{\prime \prime} \mathrm{N} \\
80^{\circ} 19^{\prime} 48^{\prime \prime} \mathrm{E}\end{array}$} \\
\hline & & Trametes sp. & Wood log & \\
\hline & Illandu Timber Depot & Daedaleopsis confragosa & Wood log & \\
\hline & & Pycnoporus sanguineus & Dead wood & \\
\hline & & Phyllotopsis & Wood log & \\
\hline
\end{tabular}


TABle 1: Continued.

\begin{tabular}{|c|c|c|c|c|}
\hline Site Number & Site name & Strain name & Source & Altitude \\
\hline \multirow{3}{*}{6} & \multirow{3}{*}{ Kothagudem } & Piptoporus betulinus & Tree & \multirow{3}{*}{$\begin{array}{l}17^{\circ} 33^{\prime} 0^{\prime \prime} \mathrm{N} \\
80^{\circ} 37^{\prime} 48^{\prime \prime} \mathrm{E}\end{array}$} \\
\hline & & Trametes sp. & Wood log & \\
\hline & & Ganoderma sp. & Wood log & \\
\hline \multirow{4}{*}{7} & \multirow{4}{*}{ Narsampet } & Ganoderma sp. & Wood log & \multirow{4}{*}{$\begin{array}{l}17^{\circ} 55^{\prime} 35.02^{\prime \prime} \mathrm{N} \\
79^{\circ} 53^{\prime} 48.99^{\prime \prime} \mathrm{E}\end{array}$} \\
\hline & & Daedaleopsis sp. & Wood log & \\
\hline & & Trametes sp. & Wood log & \\
\hline & & Pycnoporus sp. & & \\
\hline \multirow{2}{*}{8} & \multirow{2}{*}{ Khammam } & Schizophyllum commune & Wood log & \multirow{2}{*}{$\begin{array}{c}17^{\circ} 15^{\prime} 0^{\prime \prime} \mathrm{N} \\
80^{\circ} 9^{\prime} 0^{\prime \prime} \mathrm{E}\end{array}$} \\
\hline & & Trametes sp. & Wood log & \\
\hline
\end{tabular}

TABLE 2: Classification of identified wild mushrooms.

\begin{tabular}{|c|c|c|c|c|c|c|}
\hline Division & Class & Order & Family & Genus & Species & Place \\
\hline Basidiomycota & Agaricomycetes & Polyporales & Polyporaceae & $\begin{array}{l}\text { Trametes } \\
\text { Trametes } \\
\text { Trametes } \\
\text { Ganoderma } \\
\text { Daedaleopsis } \\
\text { Trametes } \\
\text { Trametes }\end{array}$ & $\begin{array}{c}\text { versicolor } \\
\text { hirsuta } \\
\text { elegans voucher } \\
\text { lucidum } \\
\text { flavida } \\
\text { gibbosa } \\
\text { elegans }\end{array}$ & $\begin{array}{c}\text { Etunagaram } \\
\text { Etunagaram } \\
\text { Etunagaram } \\
\text { Depott } \\
\text { Bhadrachalam } \\
\text { Etunagaram } \\
\text { Etunagaram } \\
\text { Depot }\end{array}$ \\
\hline Basidiomycota & Basidiomycetes & Polyporales & Polyporaceae & $\begin{array}{r}\text { Pycnoporus } \\
\text { Fomitopsis } \\
\end{array}$ & $\begin{array}{c}\text { cinnabarinus } \\
\text { feei }\end{array}$ & $\begin{array}{l}\text { Etunagaram } \\
\text { Etunagaram }\end{array}$ \\
\hline Basidiomycota & Basidiomycetes & Agaricales & Schizophyllaceae & Schizophyllum & radiatum & Khammam \\
\hline
\end{tabular}

and other properties [21]. Study on mushrooms in South India such as Tamil Nadu, Kerala, Karnataka, and Andhra Pradesh was neglected as regards to studies on agarics until 1975 [22]. All these collected white rot fungi were rich in medical importance. Ganoderma lucidum is well known to promote health and longevity, lowers the risk of cancer and heart disease, and boosts the immune system [23]. Polysaccharides from mushrooms as anticancer agents, other constituents exhibiting antioxidants and antihypertensive, cholesterol-lowering, liver protection, antifibrotic, anti-inflammatory, antidiabetic, antiviral, and antimicrobiallike activities, have overtly primed its potential as dietary supplements [24]. Some of the Indian mushrooms which are having the medicinal properties are Agaricus bisporus [25], Astraeus hygrometricus [26], Volvariella bombycina [27], Ramaria formosa [28], Pleurotus sajor-caju [29], Pleurotus pulmonarius [30], Pleurotus ostreatus [31], Phellinus rimosus [32, 33], Lycoperdon perlatum [34], Lentinus tuber-regium [35], and Lentinus squarrosulus [36]. One of the authors [37] worked on Schizophyllum radiatum and reported the potentials of extracellular biosynthesis of silver nanoparticles, their characterization, and antimicrobial activity on grampositive and gram-negative bacteria. The S. radiatum was also studied for its antimicrobial and antioxidative properties under submerged fermentation. The supernatant of the seed media obtained after separating the mycelia has been used for the synthesis of silver nanoparticles, whereas the species of Fomitopsis feei were recorded in decolorization of triphenyl methane dyes, namely, bromophenol blue, basic fuchsin, methyl violet, methyl green, ethyl violet, and malachite green [38]. This report clearly explains that the bioremediation by utilising fungal organisms was advised to be the costeffective and ecofriendly method of decolorization of effluents released from the dye industries. The genus Trametes and its species have many immunomodulatory and anticancer effects [39]. The genus of Daedaleopsis has antibiotic, antihypersensitive, and antitumour properties [40].

A constant monitoring and collection, identification, and preservation of the wild mushrooms are the need of the hour to explore and make use of the bioprospects of the diversified macrofungal species. This is a preliminary and basic work carried out to locate and identify the bioprospects of the existing macrofungi which will pave the way for understanding an elaborate study on this aspect.

\section{Conclusion}

Amongst the vast number of living forms very little amount of attention has been paid to conservation of fungal biodiversity. Due to loss of natural habitats, soil and air pollution expansion of monocropping and loss of genetic diversity many fungal species are on threat. For the smooth working of this terrestrial environment, the preservation of mushroom differences is discriminating. Keeping in view this gigantic mushroom treasure it is the high time to completely save this biodiversity. A few mushrooms are known to be the 
TABLE 3: Mycological characters of identified wild mushrooms.

\begin{tabular}{|c|c|c|c|c|c|c|c|}
\hline Name & Hymenium type & Cap shape & Which gills & Stipe character & $\begin{array}{l}\text { Spore print } \\
\text { colour }\end{array}$ & $\begin{array}{c}\text { Ecological } \\
\text { type }\end{array}$ & Edibility \\
\hline T. versicolor & Pores & Offset or distinct & Decurrent & - & $\begin{array}{l}\text { White to } \\
\text { yellow }\end{array}$ & Saprotrophic & $\begin{array}{l}\text { Edible but } \\
\text { unpalatable }\end{array}$ \\
\hline T. hirsuta & Pores & Distinct & Decurrent & Bare & Cream & Saprotrophic & Inedible \\
\hline T. elegans voucher & Pores and gills & No distinct cap & Decurrent & - & White & Saprotrophic & Inedible \\
\hline Ganoderma lucidum & Pores & Offset or indistinct & Irregular & Bare & Brown & Saprotrophic & Edible \\
\hline Daedaleopsis flavida & Pores & No distinct cap & Decurrent & - & White & Saprotrophic & Inedible \\
\hline T. gibbosa & Pores & Offset & Decurrent & Bare & $\begin{array}{l}\text { White to } \\
\text { cream }\end{array}$ & Saprotrophic & Inedible \\
\hline T. elegans & Pores & Distinct & Decurrent & Bare & Cream & Saprotrophic & Inedible \\
\hline Pycnoporus cinnabarinus & Pores & Distinct & Decurrent & Bare & Cream & Saprotrophic & Inedible \\
\hline Fomitopsis feei & Pores & No distinct cap & Decurrent & - & Brown & Saprotrophic & Inedible \\
\hline Schizophyllum communae & Pores & Offset or indistinct & Decurrent & - & White & Saprotrophic & Inedible \\
\hline
\end{tabular}

wellsprings of different bioactive substances like antibacterial, antifungal, antiviral, antiparasitic, antioxidant, antiinflammatory, antiproliferative, anticancer, antitumour, cytotoxic, anti-HIV, hypocholesterolemic, antidiabetic, anticoagulant, and hepatoprotective substances, among others. These mushrooms have been utilized as ethnomedicines by tribals for treatment of different sicknesses. Numerous mushrooms still stay unreported and their healthful and in addition medical advantages are obscure to us. Henceforth, an opportune examination in regard to isolation, identification, and characterization of the current mushroom vegetation is vital. Biotechnological devices can be utilized with a specific end goal to accomplish the in situ and ex situ preservation of huge numbers of the mushroom species. The outcome of the present study elaborates the information on the facts and figures of diversity of fungi of the study area.

\section{Conflict of Interests}

The authors declare that there is no conflict of interests regarding the publication of this paper.

\section{References}

[1] D. L. Hawksworth, P. M. Kirk, B. C. Sutton, and D. M. Pegler, Ainsworth \& Bisby's Dictionary of the Fungi, CAB International, Wallingford, UK, 8th edition, 1995.

[2] P. Wongchalee and C. Pukahute, "Diversity of mushrooms in Dry Dipterocarp forest at Phuphan National Park, Sakon Nakhon Province," Natural Science, vol. 4, no. 12, pp. 1153-1160, 2012.

[3] E. E. Andrew, T. R. Kinge, E. M. Tabi, N. Thiobal,, and A. M. Mih, "Diversity and distribution of macrofungi (mushrooms) in the Mount Cameroon Region," Journal of Environmental Microbiology, vol. 3, pp. 318-334, 2013.

[4] R. P. Metuku, S. Burra, H. Nidadavolu, S. Pabba, and M. A. Singaracharya, "Selection of highest lignolytic white rot fungus and its molecular identification," Journal of Cell and Tissue Research, vol. 11, no. 1, pp. 2557-2562, 2011.
[5] M. D. M. Jones, I. Forn, C. Gadelha et al., "Discovery of novel intermediate forms redefines the fungal tree of life," Nature, vol. 474, no. 7350, pp. 200-204, 2011.

[6] Y. Liu, J. He, G. Shi, L. An, M. Öpik, and H. Feng, "Diverse communities of arbuscular mycorrhizal fungi inhabit sites with very high altitude in Tibet Plateau," FEMS Microbiology Ecology, vol. 78, no. 2, pp. 355-365, 2011.

[7] T. T. Chang and W. N. Chou, "Antrodia cinnamomea sp. nov. on Cinnamomum kanehirai in Taiwan," Mycological Research, vol. 99, no. 6, pp. 756-758, 1995.

[8] C. Manoharachary, K. Sridhar, R. Singh et al., "Fungal biodiversity: distribution, conservation and prospecting of fungi from India," Current Science, vol. 89, no. 1, pp. 58-71, 2005.

[9] S. K. Deshmukh, "Biodiversity of tropical basidiomycetes as sources of novel secondary metabolites," in Microbiology and Biotechnology for Sustainable Development, P. C. Jain, Ed., pp. 121-140, CBS Publishers and Distributors, New Delhi, India, 2004.

[10] A. V. Sathe and S. M. Kulkarni, "A checklist of wild edible mushrooms from South-West India," in Indian Mushroom Science II, T. N. Kaul and B. M. Kapur, Eds., pp. 411-413, Regional Research Laboratory, Jammu, India, 1987.

[11] E. J. Butler and G. R. Bisby, The Fungi of India, Science Monograph No. 1, The Imperial Council of Agricultural Research, Calcutta, India, 1931.

[12] R. S. Vasudev, The Fungi of India, ICAR Publications, New Delhi, India, 1960.

[13] K. S. Bilgrami, Jammludin, and M. A. Rizvi, Fungi of India. Part-II, Today \& Tomorrow Printers and Publishers, New Delhi, India, 1979.

[14] K. Bolla, S. V. S. S. S. L. N. Hima Bindu, S. Burra, and M. A. SingaraCharya, "Effect of plant oils, surfactants and organic acids on the production of mycelial biomass and exopolysaccharides of Trametes spp.", Journal of Agricultural Technology, vol. 7, pp. 957-965, 2011.

[15] T. T. Chang and W. N. Chou, "Antrodia cinnamomea sp. nov. on Cinnamomum kanehirai in Taiwan," Mycological Research, vol. 99, no. 6, pp. 756-758, 1995.

[16] S. O. Rogers and A. J. Bendich, "Extraction of total cellular DNA from plants, algae and fungi," in Plant Molecular Biology Manual D1, S. B. Gelvin and R. A. Schilperoort, Eds., pp. 1-8, Kluwer Academic Publishers, Boston, Mass, USA, 1994. 
[17] T. J. White, T. Bruns, S. Lee, and J. Taylor, "Amplification and direct sequencing of fungal ribosomal RNA genes for phylogenetics," in PCR Protocols: A Guide to Methods and Applications, M. A. Innis, D. H. Gelfand, J. J. Sninsky, and T. J. White, Eds., pp. 315-322, Academic Press, San, Diego, Calif, USA, 1990.

[18] T. Hall, BioEdit Version 6.0.7, Department of Microbiology, North Carolina State University, 2004, http://www.mbio.ncsu .edu/BioEdit/bioedit.html.

[19] D. L. Swofford, PAUP: Phylogenetic Analysis Using Parsimony Version 4.0b10, Sinauer Associates, Sunderland, Mass, USA, 2002.

[20] M. Rai, G. Tidke, and S. P. Wasser, "Therapeutic potential of mushrooms," Natural Product Radiance, vol. 4, pp. 246-257, 2005.

[21] H. Thatoi and S. K. Singdevsachan, "Diversity, nutritional composition and medicinal potential of Indian mushrooms: a review," African Journal of Biotechnology, vol. 13, no. 4, pp. 523$545,2014$.

[22] K. Natarajan, "Mushroom flora of South India (except Kerala)," in Advances in Horticulture 13 Mushroom, K. L. Chadha and S. R. Sharma, Eds., pp. 381-397, Malhotra Publishing House, New Delhi, India, 1995.

[23] S. Wachtel-Galor, B. Tomlinson, and I. F. F. Benzie, "Ganoderma lucidum ("Lingzhi"), a Chinese medicinal mushroom: biomarker responses in a controlled human supplementation study," British Journal of Nutrition, vol. 91, no. 2, pp. 263-269, 2004.

[24] J. K. Zjawiony, "Biologically active compounds from Aphyllophorales (polypore) fungi," Journal of Natural Products, vol. 67, no. 2, pp. 300-310, 2004.

[25] L. K. Jagadish, V. V. Krishnan, R. Shenbhagaraman, and V. Kaviyarasan, "Comparitive study on the antioxidant, anticancer and antimicrobial property of Agaricus bisporus (J. E. Lange) Imbach before and after boiling," African Journal of Biotechnology, vol. 8, no. 4, pp. 654-661, 2009.

[26] I. Chakraborty, S. Mondal, M. Pramanik, D. Rout, and S. S. Islam, "Structural investigation of a water-soluble glucan from an edible mushroom, Astraeus hygrometricus," Carbohydrate Research, vol. 339, no. 13, pp. 2249-2254, 2004.

[27] R. Jagadeesh, N. Raaman, K. Periyasamy et al., "Proximate analysis and antibacterial activity of edible mushroom Volvariella bombycina," International Journal of Microbiology Research, vol. 3, pp. 110-113, 2010.

[28] C. Ramesh and M. G. Pattar, "Antimicrobial properties, antioxidant activity and bioactive compounds from six wild edible mushrooms of western ghats of Karnataka, India," Pharmacognosy Research, vol. 2, no. 2, pp. 107-112, 2010.

[29] D. H. Tambekar, T. P. Sonar, M. V. Khodke, and B. S. Khante, "The novel antibacterials from two edible mushrooms: Agaricus bisporus and Pleurotus sajor caju," International Journal of Pharmacology, vol. 2, no. 5, pp. 582-585, 2006.

[30] N. Jose, T. A. Ajith, and K. K. Janardhanan, "Antioxidant, antiinflammatory and antitumor activities of culinarymedicinal mushroom Pleurotus pulmonarius (Fr.) Quel. (Agaricomycetideae)," International Journal of Medicinal Mushrooms, vol. 4, no. 4, pp. 329-335, 2002.

[31] K. K. Maity, S. Patra, B. Dey et al., "A heteropolysaccharide from aqueous extract of an edible mushroom, Pleurotus ostreatus cultivar: structural and biological studies," Carbohydrate Research, vol. 346, no. 2, pp. 366-372, 2011.
[32] T. A. Ajith and K. K. Janardhanan, "Antioxidant and antiinflammatory activities of methanol extract of Phellinus rimosus (Berk) pilat," Indian Journal of Experimental Biology, vol. 39, no. 11, pp. 1166-1169, 2001.

[33] T. A. Ajith and K. K. Janardhanan, "Indian medicinal mushrooms as a source of antioxidant and antitumor agents," Journal of Clinical Biochemistry and Nutrition, vol. 40, no. 3, pp. 157-162, 2007.

[34] C. Ramesh and M. G. Pattar, "Antimicrobial properties, antioxidant activity and bioactive compounds from six wild edible mushrooms of western ghats of Karnataka, India," Pharmacognosy Research, vol. 2, no. 2, pp. 107-112, 2010.

[35] J. Manjunathan and V. Kaviyarasan, "Solvent based effectiveness of antibacterial activity of edible mushroom Lentinus tuberregium (Fr.)," International Journal of PharmTech Research, vol. 2, no. 3, pp. 1910-1912, 2010.

[36] S. K. Bhunia, B. Dey, K. K. Maity et al., "Structural characterization of an immunoenhancing heteroglycan isolated from an aqueous extract of an edible mushroom, Lentinus squarrosulus (Mont.) Singer," Carbohydrate Research, vol. 345, no. 17, pp. 2542-2549, 2010.

[37] R. P. Metuku, S. Pabba, S. Burra, S. V. S. S. S. L. N. H. Bindu, K. Gudikandula, and M. A. S. Charya, "Biosynthesis of silver nanoparticles from Schizophyllum radiatum HE 863742.1: their characterization and antimicrobial activity," 3 Biotech, vol. 4, no. 3, pp. 227-234, 2014.

[38] S. V. S. S. S. L. H. B. Nidadavolu, K. Gudikandula, S. K. Pabba, and S. C. Maringanti, "Decolorization of triphenyl methane dyes by Fomitopsis feei," Natural Science, vol. 5, no. 6, pp. 3035, 2013.

[39] J. E. Ramberg, E. D. Nelson, and R. A. Sinnott, "Immunomodulatory dietary polysaccharides: a systematic review of the literature," Nutrition Journal, vol. 9, article 54, 2010.

[40] K. Das, "Diversity and conservation of wild mushrooms in Sikkim with special reference to Barsey Rhododendron Sanctuary," NeBIO, vol. 1, pp. 1-13, 2010. 

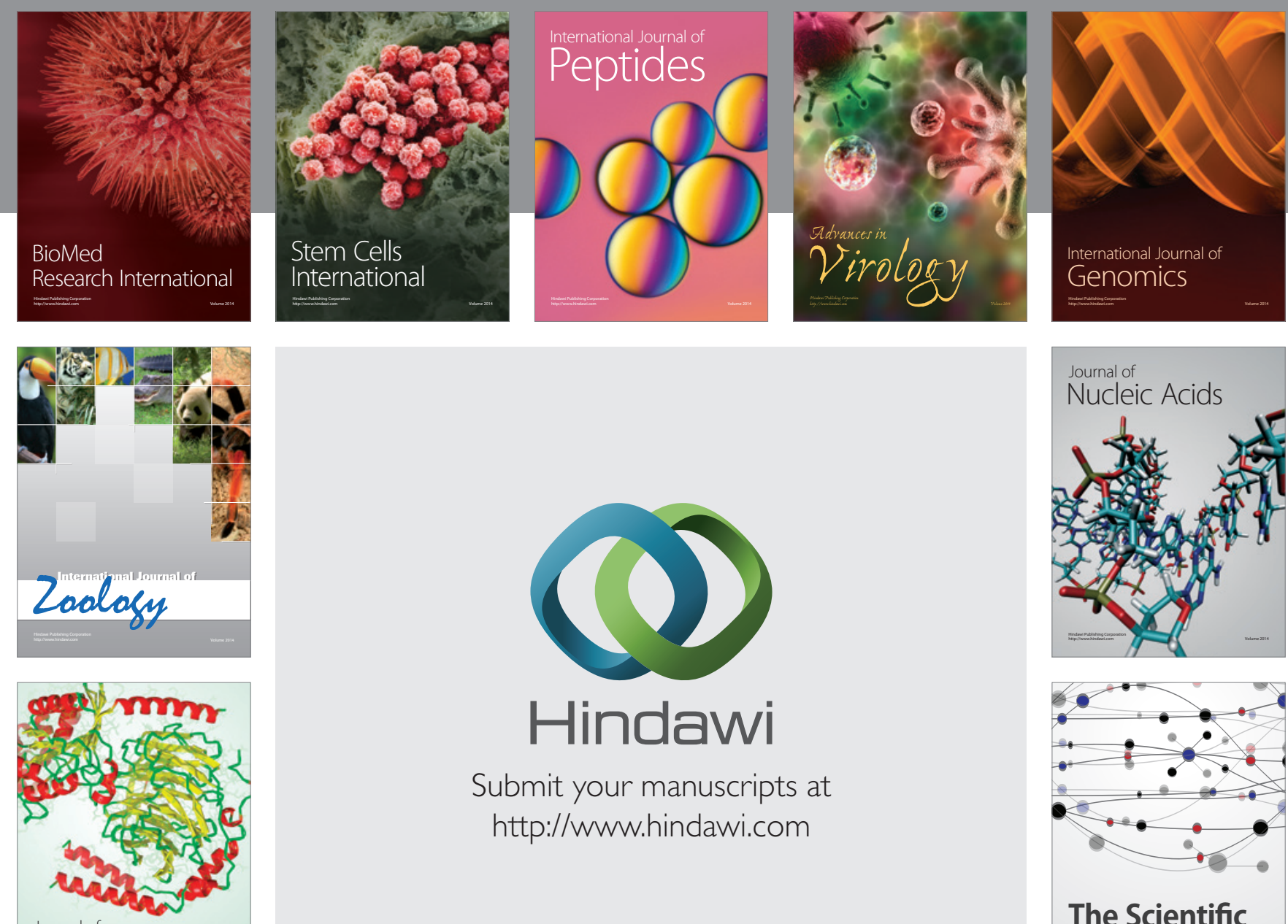

Submit your manuscripts at

http://www.hindawi.com

Journal of
Signal Transduction
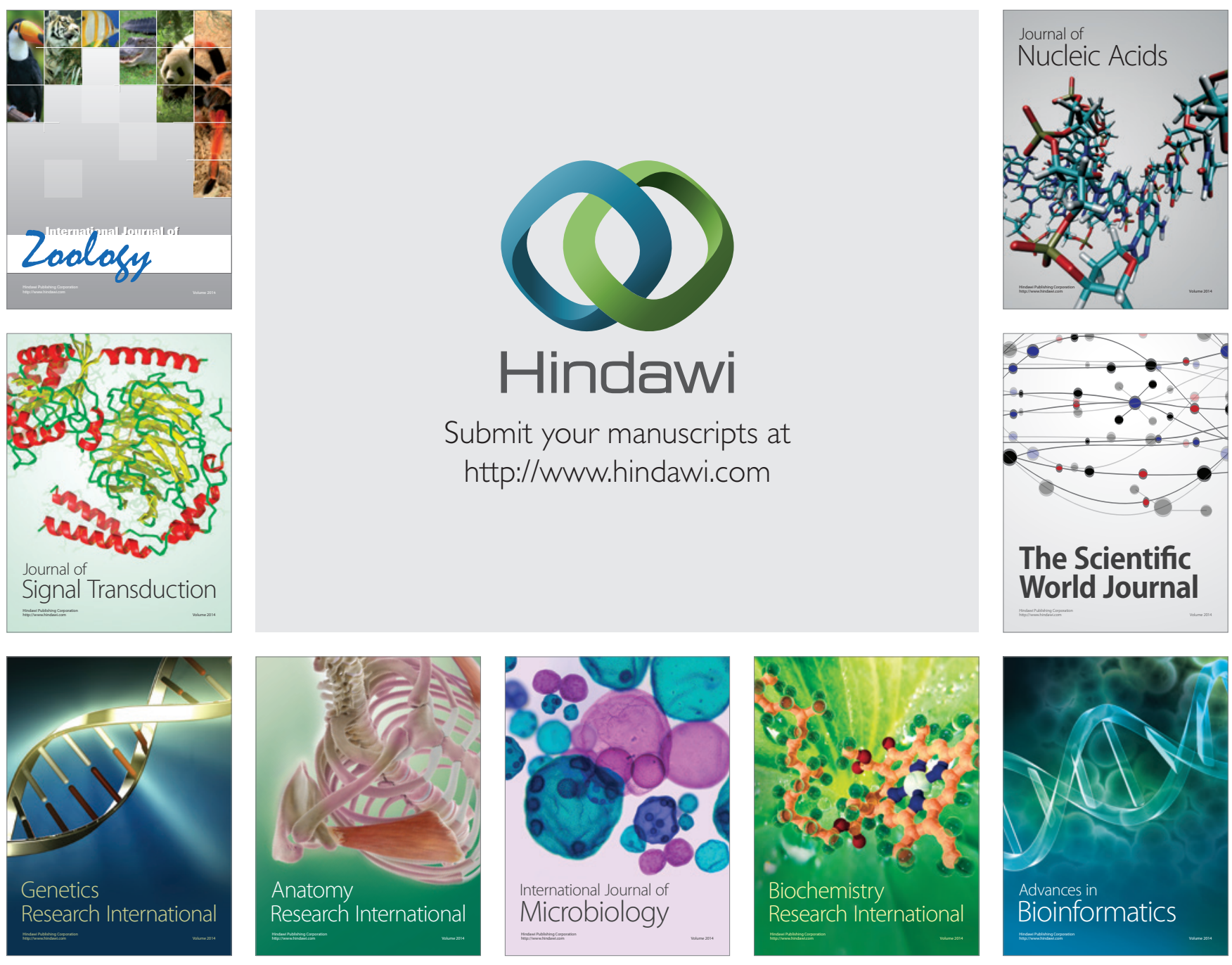

The Scientific World Journal
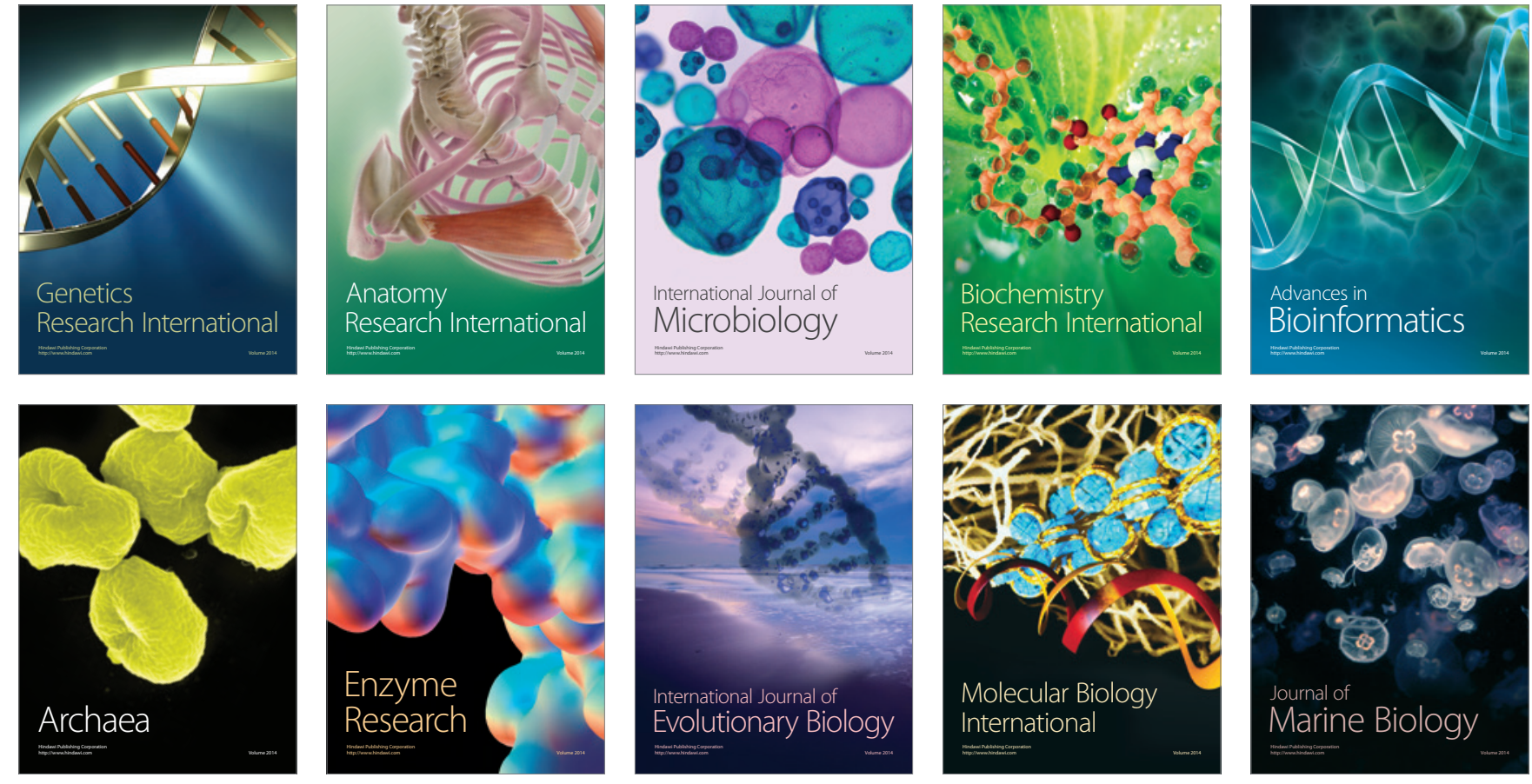